\title{
Beneficial Effects of Cholecystokinin-receptor Blockade and Inhibition of Proteolytic Enzyme Activity in Experimental Acute Hemorrhagic Pancreatitis in Mice \\ Evidence for Cholecystokinin as a Major Factor in the Development of Acute Pancreatitis
}

Claus Niederau, Rodger A. Liddle, Linda D. Ferrell, and James H. Grendell

Medical Service, San Francisco General Hospital, San Francisco, California 94110; Cell Biology Laboratory, Harold Brunn Institute, Mount Zion Hospital and Medical Center, San Francisco, California 94120; and Departments of Medicine,

Pathology, and Physiology, University of California, San Francisco, California 94143

\begin{abstract}
The effects of the cholecystokinin (CCK)-receptor antagonist proglumide, the protease inhibitor gabexate, and the hormones secretin and cholecystokinin-octapeptide (CCK-8) were studied in a model of acute hemorrhagic pancreatitis induced by feeding mice a choline-deficient, ethionine-supplemented (CDE) diet. Injections of gabexate and proglumide from initiation of CDE diet (before induction of pancreatitis) increased survival from $37 \%$ (diet alone) to 85 and $75 \%$, respectively, and also ameliorated histological alterations and increases in serum amylase concentration and pancreatic activated trypsin. Secretin had no major beneficial effect. When proglumide or gabexate were given after induction of pancreatitis, proglumide still increased survival to $75 \%$, whereas gabexate no longer did. Injection of nontoxic doses of CCK-8 before proglumide or gabexate injections completely abolished all beneficial effects and also increased the severity of pancreatitis due to CDE diet alone. Blockade of CCK receptors and early inhibition of protease activity may be beneficial in severe acute pancreatitis. Cholecystokinin appears to play a contributory role in the development of pancreatitis.
\end{abstract}

\section{Introduction}

Severe acute hemorrhagic or necrotizing pancreatitis continues to result in significant morbidity and mortality. No specific therapy beyond supportive care has been proven to be clinically effective. The recent development of noninvasive, reproducible models of acute pancreatitis now enables us to study a variety of potentially beneficial agents.

We have previously shown that the cholecystokinin (CCK) ${ }^{1}$ receptor antagonist proglumide had protective effects against

Portions of this work were presented at the annual meeting of the American Gastroenterological Association, New York, NY, 14 May 1985; and have been published in abstract form, 1985. Gastroenterology. 88:1518.

Address correspondence to Dr. Grendell, Gastrointestinal Unit, 3C19, San Francisco General Hospital, 1001 Potrero Ave., San Francisco, CA 94110.

Received for publication 4 February 1986.

1. Abbreviations used in this paper: CCK, cholecystokinin; CCK-8, cholecystokinin-octapeptide; $\mathrm{CDE}$, choline-deficient, ethionine-supplemented; E, eosin; H, hematoxylin; s.c., subcutaneous.

J. Clin. Invest.

(c) The American Society for Clinical Investigation, Inc.

0021-9738/86/10/1056/08 $\$ 1.00$

Volume 78, October 1986, 1056-1063 caerulein-induced acute pancreatitis in mice, whereas secretin had only minor effects in this model (1). Secretin had previously been proposed to have major beneficial effects on caeruleininduced pancreatitis in rats (2) and in dogs (3). The recently developed serine protease inhibitor gabexate mesilate also had protective effects against acute experimental pancreatitis in rats (4).

This study was performed to further evaluate the effects of gabexate, proglumide, and secretin in a model of acute hemorrhagic pancreatitis induced by feeding a choline-deficient, ethionine-supplemented (CDE) diet to young female mice (5). The study was designed to investigate not only protective (prophylactic) effects, but also potentially therapeutic effects of these agents, once pancreatitis had already developed.

\section{Methods}

Materials. Gabexate mesilate was a generous gift from Sanol-Schwarz (Monheim, Federal Republic of Germany). Proglumide was a generous gift from Rotta Laboratorium (Milan, Italy) and Barrows Research Group, Inc. (Valley Stream, NY). Secretin (Kabi, Studsvik, Sweden) was purchased from Pharmacia Fine Chemicals (Piscataway, NJ), and cholecytokinin-octapeptide (CCK-8) was purchased from Squibb (Princeton, $\mathrm{NJ}$ ).

\section{Experimental protocol}

Female Swiss Webster mice (Simonsen Laboratories, Gilroy, CA), 4-6 wk old and weighing 10-14 g, were used in this study. All mice were fed regular laboratory chow ad libitum before the experiments. The ethioninesupplemented (0.5\% ethionine), choline-deficient (CDE) diet (test diet, Teklad, Madison, WI) was then substituted for a period of $66 \mathrm{~h}$, after which it was replaced by regular chow. Mice were randomly assigned to the different treatment groups. For all conditions studied, unless otherwise indicated, blood samples and pancreatic tissue were collected from mice that had been fed the CDE diet for $54 \mathrm{~h}$ (six mice per set of determinations). These mice were not included in the survival analysis.

The first set of experiments examined whether any of the agents being studied were protective if given before the onset of pancreatitis (prophylactic regimen). Separate groups of mice received subcutaneous injection of either $100 \mathrm{mg} / \mathrm{kg}$ gabexate mesilate, $400 \mathrm{mg} / \mathrm{kg}$ proglumide, $25 \mathrm{U} / \mathrm{kg}$ secretin, or $0.9 \%$ saline at 6-h intervals throughout the entire 66-h CDE-diet feeding period (12 injections per animal). In related experiments in other groups of animals, $2 \mu \mathrm{g} / \mathrm{kg} \mathrm{CCK}-8$ was administered subcutaneously 10 min before each of the 12 gabexate, proglumide, or saline injections given CDE diet-fed mice. As a control experiment, the same dose and regimen of CCK-8 injections were given $10 \mathrm{~min}$ before saline injections to normal chow-fed mice.

Because gabexate and proglumide were found to be protective when given before the onset of pancreatitis in the first set of experiments, a second set was performed to determine whether these agents were still protective once pancreatitis had already been induced (therapeutic regimen). Control experiments were first performed in which mice were fed 
the $\mathrm{CDE}$ diet for $33 \mathrm{~h}$ and received saline injections every $6 \mathrm{~h}$. These mice were then either killed at $33 \mathrm{~h}$ or placed back on regular chow and killed at $54 \mathrm{~h}$. After determination that a 33-h period on the CDE diet already resulted in induction of acute pancreatitis, separate groups of mice received subcutaneous injections of either gabexate $(100 \mathrm{mg} / \mathrm{kg})$ or proglumide $(400 \mathrm{mg} / \mathrm{kg})$ at $6-\mathrm{h}$ intervals only during the final $33 \mathrm{~h}$ of a 66-h period on the CDE diet.

For all experimental conditions and regimens, all surviving mice were observed for 1 wk after the beginning of the experiment; of the mice that did not survive, all died within a 90 -h period from the start of the experiment.

\section{Biochemical determinations}

Blood samples were collected from mixed arteriovenous blood after decapitation of the animals. Serum amylase concentration was determined after centrifugation of blood samples at $10,000 \mathrm{~g}$ for $10 \mathrm{~min}$ using the Phadebas amylase test (Pharmacia Fine Chemicals).

For determination of activated trypsin in pancreatic tissue, the pancreas was quickly removed and $75 \mathrm{mg}$ of it was suspended in $2.5 \mathrm{ml}$ of ice-cold $5 \mathrm{mM} \mathrm{MgCl}_{2}$ solution containing $0.1 \%$ Triton X-100, and homogenized using an electrically driven teflon-glass pestle. All debris and nuclei were removed by centrifugation at $4^{\circ} \mathrm{C}$ for $20 \mathrm{~min}$ at $3,000 \mathrm{~g}$ and the supernatant was centrifuged at $100,000 \mathrm{~g}$ for $1 \mathrm{~h}(6)$. The supernatant was assayed for free tryptic activity by a fluorometric assay using $\mathrm{N}$-carbobenzoxy-glycyl-glycyl-L-arginine-2-naphthylamide hydrochloride (GANA; Bachem, Inc., Torrance, CA) as substrate (7). The protein concentration in the supernatant was determined using the Lowry method with bovine serum albumin as a standard (8).

\section{Measurement of plasma CCK}

Collection of plasma. Mice were allowed free access to food during the entire study period, except for one group of chow-fed animals which were fasted overnight. Animals were killed by decapitation, and trunk blood was collected into iced heparinized tubes. The amount of blood obtained from each mouse ranged from 0.2 to $0.3 \mathrm{ml}$; therefore, blood samples from 6 to 8 mice from the same treatment group were pooled for each CCK determination. Blood was centrifuged at $4^{\circ} \mathrm{C}$ for recovery of plasma.

Assay of plasma CCK. Plasma CCK was measured by bioassay as previously described for rat and human plasma $(9,10)$. In brief, CCK was extracted from mouse plasma by adsorption on octadecylsilylsilica cartridges (Sep-Pak; Waters Associates, Milford, MA) and eluted with 1 $\mathrm{ml}$ of $80 \%$ ethanol and $0.2 \%$ trifluoroacetic acid $(4: 1$, vol/vol) into incubation vials and dried under nitrogen. CCK in these extracts was quantified by its ability to stimulate amylase release from isolated rat pancreatic acini, prepared by collagenase digestion of rat pancreas. Values were compared with a standard curve of CCK-8 and results were expressed as CCK-8 equivalents (pM). The assay was sensitive to CCK levels as low as $1 \mathrm{pM}$; and with the ability to concentrate plasma up to four-fold (by adsorbing $4 \mathrm{ml}$ of plasma onto a single Sep-Pak and eluting it in 1 $\mathrm{ml}$ ), plasma CCK levels as low as $0.25 \mathrm{pM}$ could be detected.

Several pieces of evidence verified that the amylase stimulatory properties of mouse plasma extracts on isolated pancreatic acini were indeed due to CCK, as previously demonstrated for rat and human plasma extracts $(9,10)$. First, CCK bioactivity in plasma was completely inhibited by the CCK antagonist, dibutyryl cyclic guanosine monophosphate (dibutyryl cGMP). Second, maximum secretory concentrations of vasoactive intestinal peptide, a pancreatic secretagogue that increases intracellular cyclic AMP (cAMP) levels, did not modify the calculated concentrations of CCK in plasma. Third, plasma bioactivity was not inhibited by atropine, which indicates that muscarinic agents were not contributing to amylase release from the acini preparation. In addition, there was little interference from gastrin as it was only 0.001 times as potent as CCK8 in this system. The recovery of CCK bioactivity when exogenous CCK8 was added to plasma from fasted mice was $90 \pm 7 \%$ (mean \pm SEM, $n=6)$.

\section{Histological analysis}

For light microscopy, the whole pancreases of the animals were quickly removed and fixed overnight at room temperature in $10 \%$ formaldehyde buffered to $\mathrm{pH} 7.0$ with $0.1 \mathrm{M}$ phosphate buffer. Tissue was subsequently embedded in paraffin, sectioned into 5- $\mu \mathrm{m}$ slices, and stained with hematoxylin $(\mathrm{H})$ and eosin $(\mathrm{E})$. The stained sections were coded. The participating pathologist (Dr. Ferrell) analyzed and graded the histological alterations of the coded sections without knowing the experimental design. The code was broken after the results had been written in a prepared table form. The details of the histological gradings are given in the legend to Table II and have previously been published (1).

\section{Statistical analysis}

Survival data of the different treatment groups were compared with survival in the control group of saline-injected, CDE-fed mice using a twotailed chi-square test. A two-tailed $t$ test for independent samples was used to compare plasma CCK concentrations, serum amylase concentrations, and the amount of activated trypsin in the pancreas. Significance was assumed for $P<0.05$.

\section{Results}

Effects of the CDE diet. Only $37 \%$ of mice that were fed the CDE diet and received saline injections survived (Table I, Fig.

Table I. Survival and Biochemical Alterations

\begin{tabular}{|c|c|c|c|c|}
\hline & Survival & & $\begin{array}{l}\text { Serum } \\
\text { amylase }\end{array}$ & $\begin{array}{l}\text { Pancreatic } \\
\text { activated } \\
\text { trypsin }\end{array}$ \\
\hline & $n /$ total & percent & $\mu g / m l$ & $n g / m l$ protein \\
\hline \multicolumn{5}{|l|}{$\begin{array}{l}\text { CDE diet (regular } \\
\text { protocol) }\end{array}$} \\
\hline Saline & $11 / 30$ & 37 & $159 \pm 12$ & $31 \pm 3$ \\
\hline Saline + CCK-8 & $5 / 24$ & 21 & $283 \pm 5^{*}$ & $44 \pm 5 \ddagger$ \\
\hline Gabexate A & $17 / 20^{*}$ & 85 & $28 \pm 6^{*}$ & $4 \pm 5^{*}$ \\
\hline Gabexate B & $8 / 20$ & 40 & $164 \pm 11$ & $9 \pm 2 \ddagger$ \\
\hline \multicolumn{5}{|l|}{ Gabexate A } \\
\hline + CCK-8 & $9 / 26$ & 35 & $151 \pm 13$ & $17 \pm 4 \S$ \\
\hline Proglumide A & $15 / 20 \ddagger$ & 75 & $25 \pm 5^{*}$ & $13 \pm 3 \S$ \\
\hline Proglumide B & $15 / 20 \ddagger$ & 75 & $73 \pm 4 \S$ & $15 \pm 3 \S$ \\
\hline \multicolumn{5}{|l|}{ Proglumide A } \\
\hline + CCK-8 & $8 / 24$ & 33 & $172 \pm 5$ & $32 \pm 4$ \\
\hline Secretin & $10 / 20$ & 50 & $122 \pm 16$ & $27 \pm 4$ \\
\hline \multicolumn{5}{|l|}{$\begin{array}{l}\text { CDE diet (control } \\
\text { protocol) }\end{array}$} \\
\hline Saline, $33 \mathrm{~h}$ & ND & & $24 \pm 2$ & $<1$ \\
\hline Saline, $54 \mathrm{~h}$ & ND & & $112 \pm 9$ & $9 \pm 3$ \\
\hline \multicolumn{5}{|l|}{ Chow diet } \\
\hline Saline & ND & & $16 \pm 3$ & $<1$ \\
\hline Saline + CCK-8 & $20 / 20$ & 100 & $19 \pm 5$ & $<1$ \\
\hline
\end{tabular}

Amylase and trypsin values are given as mean \pm SE from six mice per group. Gabexate $A$ and proglumide $A$ represent experiments in which the agents were given from the start of the CDE diet (prophylactic regimen). Gabexate B and proglumide $B$ represent experiments in which the agents were given after the $\mathrm{CDE}$ diet had been fed for $33 \mathrm{~h}$ (therapeutic regimen). Regular protocol represents experiments with the regular 66-h period of feeding the CDE diet. For determination of amylase and trypsin, mice were sacrificed after $54 \mathrm{~h}$ on the CDE diet under the regular protocol (not included in survival analysis). Control protocol represents experiments in which the CDE diet was only fed for $33 \mathrm{~h}$ and was then replaced by regular chow. Some mice were sacrificed immediately after the $33 \mathrm{~h}$ (Saline, $33 \mathrm{~h}$ ), and some mice were sacrificed after $54 \mathrm{~h}$ (Saline, $54 \mathrm{~h}$ ) under this control protocol. Survival data in experiments with the regular protocol were compared with survival in the CDE-fed animals that received saline injections as a control. Amylase and trypsin values were compared with this control group by a two-tailed $t$ test for unpaired values.

ND, not determined.

$* P<0.001 ; \ddagger P<0.01 ; \S P<0.05$. 


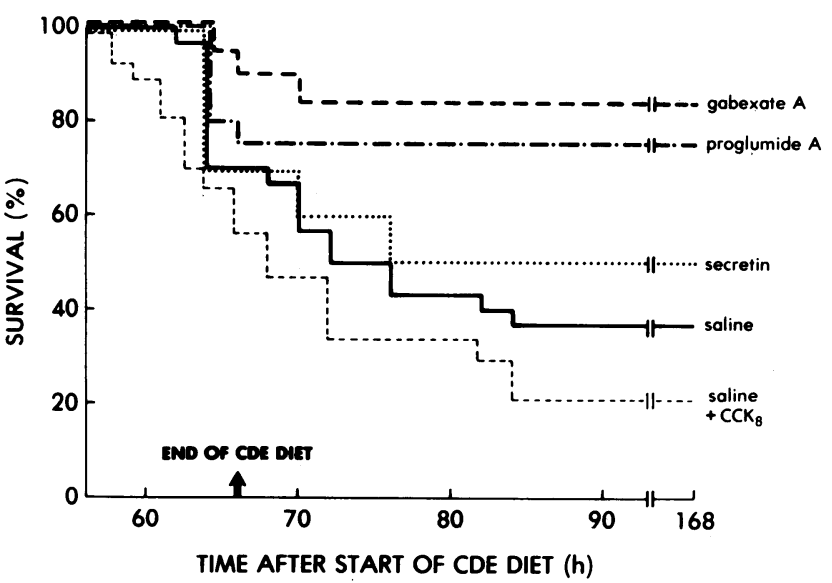

Figure 1. Cumulative survival. All substances (gabexate A, proglumide A, secretin, saline, saline + CCK-8) were given subcutaneously at 6-h intervals throughout the $66 \mathrm{~h}$ on CDE diet (prophylactic regimen). Gabexate A and proglumide A significantly increased survival compared with the saline-injected control group $(P<0.001$ and $P<0.01$, respectively, by chi-square test), whereas secretin did not alter survival $(P>0.30)$. Saline + CCK-8 produced the worst outcome $(21 \%$ survival); the difference compared with saline alone, however, was not statistically significant $(P>0.10)$. For survival data see also Table II.

1). At $54 \mathrm{~h}$ after institution of the CDE diet, there were substantial increases in serum amylase concentration and in activated trypsin in pancreatic tissue (Table I), as well as the presence of necrosis, intracellular vacuolization, and inflammation on histological examination (Table II, Fig. 2). These biochemical and morphological features and the survival data were used as the standard of comparison to evaluate the potential effects of the various agents studied on acute pancreatitis in this model.

In some experiments, mice receiving saline injections were fed the CDE diet for $33 \mathrm{~h}$ and either sacrificed at $33 \mathrm{~h}$ or switched back to regular chow and sacrificed at $54 \mathrm{~h}$. At $33 \mathrm{~h}$ there was a slight increase in serum amylase concentration and some intracellular vacuolization present but no alterations in other biochemical and histological markers (Tables I and II). However, at $54 \mathrm{~h}$ there was clear evidence of acute pancreatitis with significant increases in serum amylase concentration and activated trypsin in pancreatic tissue (Table I) and histological evidence of acinar cell necrosis, intracellular vacuolization, and inflammation (Table II). Thus, by $33 \mathrm{~h}$ on the CDE diet, acute pancreatitis had already been induced.

Effects of gabexate mesilate on CDE diet-induced pancreatitis. Prophylactic administration of this proteolytic enzyme inhibitor (i.e., starting the gabexate injection at the beginning of the CDE diet before the onset of pancreatitis) significantly improved survival from $37 \%$ in the control group to $85 \%$ (Table I, Fig. 1). Both the increases in serum amylase concentration and pancreatic activated trypsin were also markedly reduced by prophylactic treatment with gabexate (Table I). The histological features of necrosis and inflammation were essentially absent when gabexate treatment was started before the onset of pancreatitis, whereas the amount of intracellular vacuolization was only slightly reduced (Table II, Fig. 3).

In marked contrast, survival was decreased to control values when gabexate treatment was started only after a severe pancreatitis had already been induced by $33 \mathrm{~h}$ of feeding the CDE
Table II. Histological Alterations

\begin{tabular}{|c|c|c|c|}
\hline & \multicolumn{3}{|c|}{ Histological grading (0-4) } \\
\hline & Necrosis & Vacuolization & Inflammation \\
\hline \multicolumn{4}{|l|}{$\begin{array}{l}\text { CDE diet (regular } \\
\text { protocol) }\end{array}$} \\
\hline Saline & $1-2$ & $3-4$ & 1 \\
\hline Saline + CCK-8 & $3-4$ & $3-4$ & $1-2$ \\
\hline Gabexate A & 0 & 2 & 0 \\
\hline Gabexate B & 2 & 3 & 1 \\
\hline \multicolumn{4}{|l|}{ Gabexate A } \\
\hline + CCK-8 & 2 & 3 & 1 \\
\hline Proglumide A & 0 & 2 & 0 \\
\hline Proglumide B & 1 & 2 & $0-1$ \\
\hline \multicolumn{4}{|l|}{ Proglumide A } \\
\hline + CCK-8 & $1-2$ & 3 & $1-2$ \\
\hline Secretin & 1 & 3 & $0-1$ \\
\hline \multicolumn{4}{|l|}{$\begin{array}{l}\text { CDE diet (control } \\
\text { protocol) }\end{array}$} \\
\hline Saline, $33 \mathrm{~h}$ & 0 & $0-1$ & 0 \\
\hline Saline, $54 \mathrm{~h}$ & 1 & $2-3$ & $0-1$ \\
\hline \multicolumn{4}{|l|}{ Chow diet } \\
\hline Saline & 0 & 0 & 0 \\
\hline Saline + CCK-8 & 0 & 0 & 0 \\
\hline
\end{tabular}

The histological alterations were graded in a blind fashion as described previously (1). The grading refers to a scale ranging from 0 (absent) and 1 (minimal) to 4 (maximal). For necrosis and intracellular vacuolization this grading refers to an approximate percentage of cells involved: 0 , absent; $1,5-15 \% ; 2,15-35 \% ; 3,35-50 \% ; 4,>50 \%$. Gabexate $A$ and proglumide $A$ represent experiments in which the agents were given from the start of the $\mathrm{CDE}$ diet (prophylactic regimen). Gabexate $B$ and proglumide $B$ represent experiments performed in which the agents were given after the diet had been fed for $33 \mathrm{~h}$ (therapeutic regimen). Regular protocol represents experiments with the regular 66-h period of feeding the CDE diet. Histological specimens were taken after $54 \mathrm{~h}$ on the CDE diet under the regular protocol. Control protocol represents experiments in which the CDE diet was fed for 33 $\mathrm{h}$ and was then replaced by regular chow. Some mice were sacrificed immediately after the 33-h period (Saline, $33 \mathrm{~h}$ ) and some mice were sacrificed after $54 \mathrm{~h}$ (Saline, $54 \mathrm{~h}$ ) under the control protocol.

diet (Table I, Fig. 4). The increase in serum amylase concentration was virtually identical to the control value from mice that received saline injections, although the amount of pancreatic activated trypsin was significantly reduced in mice that received the therapeutic regimen of gabexate injections, as compared to the saline control (Table I). The therapeutic gabexate treatment had no effect on any of the histopathological alterations (Table II).

CCK-8 given in addition to the prophylactic gabexate injections completely abolished the beneficial effect on survival seen with the prophylactic treatment and resulted in a $35 \%$ survival rate, which is virtually identical to the control value of $37 \%$ in the saline-injected mice (Table I, Fig. 4). The increase in serum amylase concentration was also not significantly different from control, whereas the amount of activated pancreatic trypsin was still slightly decreased in the mice that received CCK-8 in addition to the prophylactic gabexate treatment as compared with 

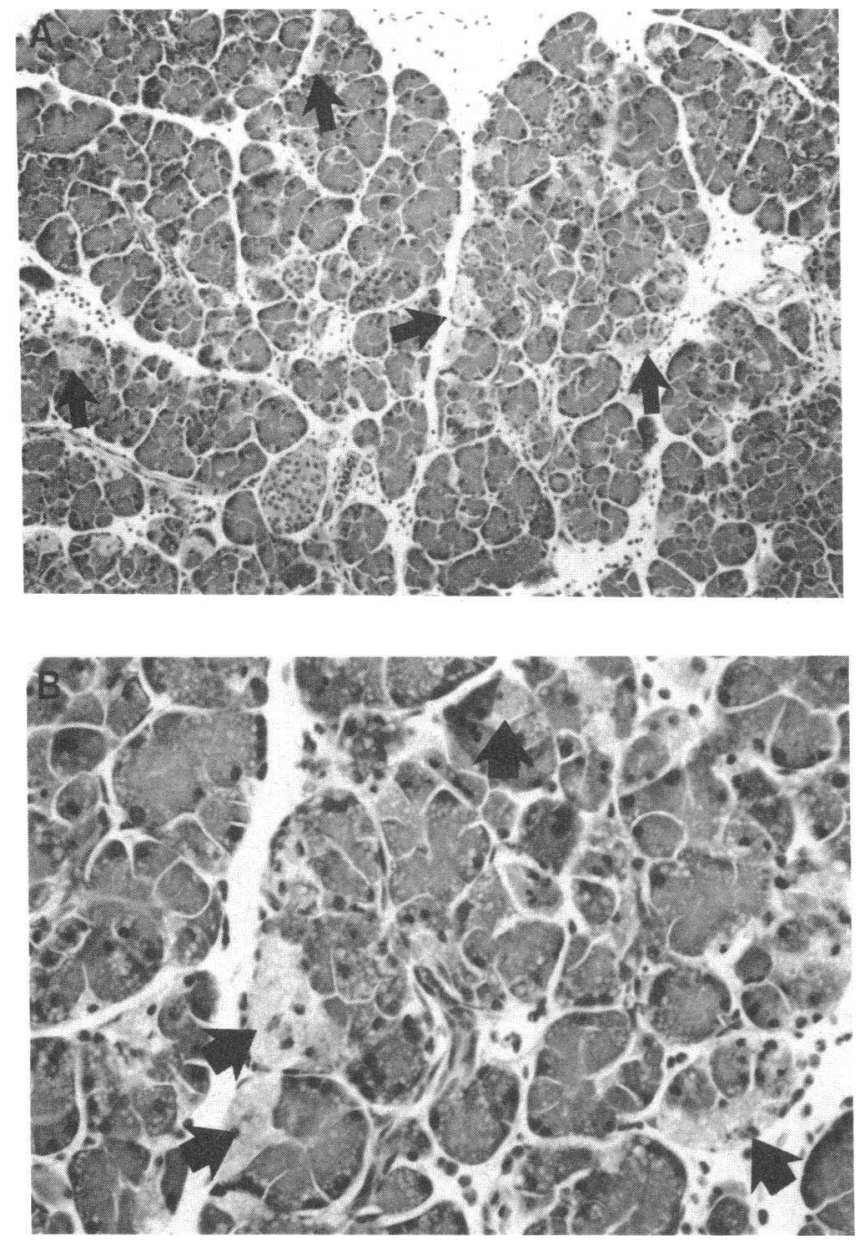

Figure 2. Pancreatic histology from mice after 54 h on the CDE diet, which received subcutaneous (s.c.) injections of $0.9 \% \mathrm{NaCl}$ as control. $(A)$ Spotty necrosis (pale areas, arrows) and inflammatory infiltrate $(H$ and $E ; \times 125)$. $(B)$ Higher magnification showing acinar cell necrosis (arrows) and intracellular vacuolization $(H$ and $E ; \times 325)$.

the saline control (Table I). CCK-8 completely abolished the beneficial effect of the prophylactic gabexate treatment seen on histological examination; all histopathological features graded were indistinguishable from the saline control (Table II).

Effects of proglumide on CDE diet-induced pancreatitis. The prophylactic treatment with proglumide had marked beneficial effects on survival and on the biochemical and morphological features of acute pancreatitis, as did gabexate. Survival was significantly improved from $37 \%$ in the saline control to $75 \%$ with the prophylactic proglumide treatment (Table I, Fig. 1). Correspondingly, both the increases in serum amylase concentration * and in pancreatic activated trypsin were markedly reduced. Necrosis and inflammation were essentially absent with the prophylactic proglumide treatment, whereas there was still a substantial amount of intracellular vacuolization (histologically similar to those mice that received the prophylactic gabexate treatment) (Table II, Fig. 5).

In contrast to the gabexate experiments, proglumide still resulted in a significant improvement in survival when given after the induction of pancreatitis (i.e., as the therapeutic regimen of injections that were started after $33 \mathrm{~h}$ of feeding the CDE diet)
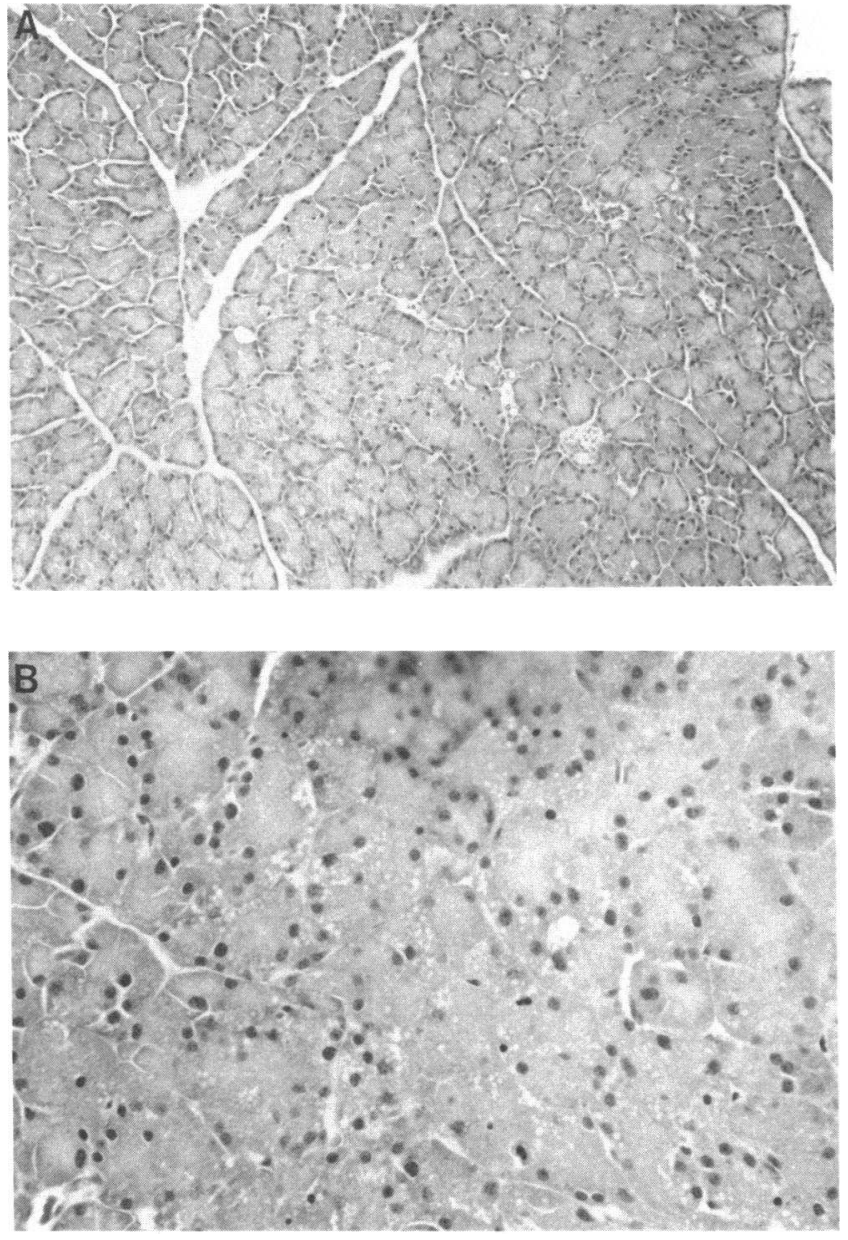

Figure 3. Pancreatic histology from mice after $54 \mathrm{~h}$ on CDE diet, which received s.c. injections of $100 \mathrm{mg} / \mathrm{kg}$ gabexate every $6 \mathrm{~h}$ while on the CDE diet. $(A)$ Architectural preservation of acinar tissue without inflammatory reaction $(H$ and $E ; \times 125)$. (B) Higher magnification showing vacuolization of acinar cells without necrosis $(H$ and $E$; $\times 325)$.

(Table I, Fig. 6). Both the increases in serum amylase and in pancreatic activated trypsin were also significantly reduced by the therapeutic proglumide treatment compared with the saline control, although to a somewhat lesser degree than seen with the prophylactic proglumide treatment (Table I). The histopathological alterations were also improved by the therapeutic proglumide treatment (Table II). However, in contrast to the results seen with the prophylactic treatment, some necrosis of acinar cells and some inflammation were present in the animals that received the therapeutic proglumide treatment (Table II).

Injections of CCK-8 in addition to the prophylactic treatment with the CCK-receptor antagonist proglumide completely abolished the beneficial effects on pancreatitis seen with the prophylactic proglumide treatment. Survival in the mice receiving CCK8 in addition to proglumide (33\%) was not significantly different from the $37 \%$ control value in the saline-injected mice (Table I, Fig. 6). Both biochemical markers, serum amylase concentration and pancreatic activated trypsin, as well as all histopathological gradings were also indistinguishable from the control data in the saline-injected mice (Tables I and II, Fig. 7).

Effects of secretin on CDE diet-induced pancreatitis. The 


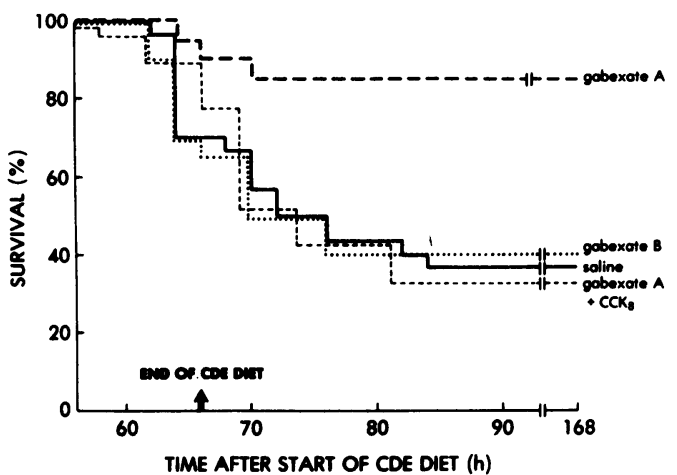

Figure 4. Cumulative survival. Gabexate A represents experiments in which gabexate was given from the beginning of the CDE diet (prophylactic regimen), whereas gabexate $B$ represents experiments in which gabexate was given only after the rats had already been fed the diet for $33 \mathrm{~h}$ (therapeutic regimen). The significant improvement in survival seen with the prophylactic regimen (gabexate $A ; P<0.001$ by chi-square test compared with the saline-injected control group) was completely lost when gabexate was given after $33 \mathrm{~h}$ on the CDE diet (gabexate B) or when injections of CCK-8 were given in addition to prophylactic gabexate treatment (gabexate A + CCK-8) $(P>0.50)$. For survival data see also Table II.

prophylactic regimen of secretin injections had no significant effect on survival compared with the saline control (Table I, Fig. 2). Correspondingly, the increases in serum amylase concentration and in pancreatic activated trypsin were also unaffected by secretin (Table I), although secretin appeared to slightly reduce the amount of necrosis, and to an even lesser degree, the amount of inflammation and intracellular vacuolization (Table II, Fig. 8).

Effects of cholecystokinin on CDE diet-induced pancreatitis. Subcutaneous injections of $2 \mu \mathrm{g} / \mathrm{kg} \mathrm{CCK}-8$ at $6-\mathrm{h}$ intervals throughout the 66-h period of feeding the CDE diet (i.e., 12 CCK injections) worsened the acute pancreatitis induced by the CDE diet alone. The increase in serum amylase concentration and in pancreatic activated trypsin were significantly greater than those caused by the diet alone (Table I); histological examination showed large areas of acinar cell necrosis and marked inflammation, as well as areas of fat necrosis and hemorrhage (Fig. 9). The gradings of these histological alterations were the most severe in any of the groups studied (Table II). Addition of CCK-8 also resulted in the worst outcome ( $21 \%$ survival). The difference compared with the $37 \%$ survival caused by the diet alone, however, did not reach statistical significance (Table I). When chowfed mice were given 12 subcutaneous injections of $2 \mu \mathrm{g} / \mathrm{kg}$ CCK8 at 6-h intervals, no adverse effects were observed (Tables I and II).

Plasma CCK concentrations. To determine whether the beneficial effects of the CCK-antagonist proglumide were related to the presence of elevated plasma CCK concentrations in mice on the CDE diet, plasma CCK concentrations were measured in mice on regular laboratory chow and in mice on the CDE diet. Chow-fed mice had fasting plasma CCK concentrations of $1.0 \pm 0.3 \mathrm{pM}$ (mean $\pm \mathrm{SD}, n=6)$ and of $7.9 \pm 1.2(n=5)$ while feeding ad libitum. Mice eating the CDE diet ad libitum had plasma concentrations of $1.2 \pm 0.2 \mathrm{pM}(n=3)$ after $15 \mathrm{~h}$ on the diet, $3.1 \pm 2.1(n=4)$ after $30 \mathrm{~h}$, and $1.7 \pm 0.7(n=7)$ after $60 \mathrm{~h}$. All values were significantly lower $(P<0.005$, two-tailed $t$ test $)$ than the plasma concentration in chow-fed animals eating ad
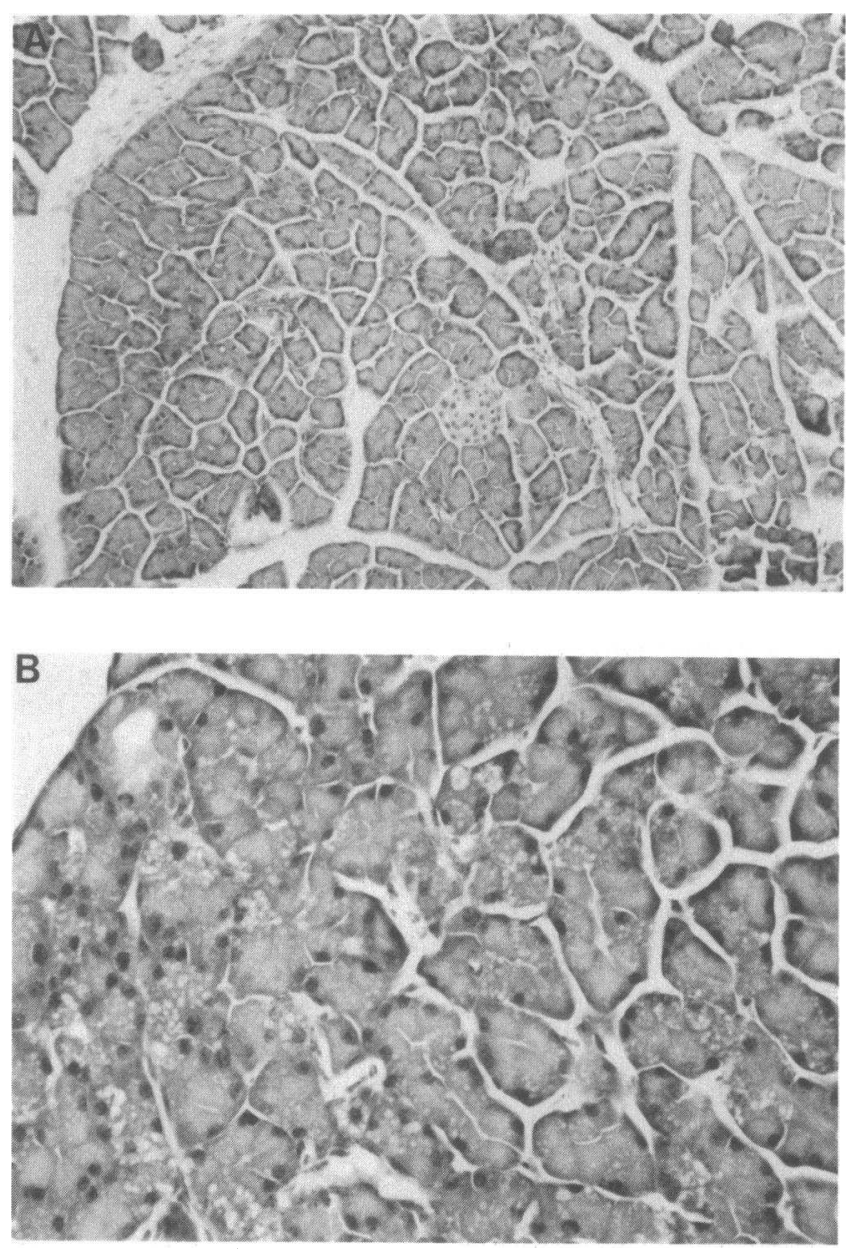

Figure 5. Pancreatic histology from mice after $54 \mathrm{~h}$ on CDE diet, which received s.c. injections of $400 \mathrm{mg} / \mathrm{kg}$ proglumide every $6 \mathrm{~h}$ while on the CDE diet. (A) Architectural preservation of acinar tissue without inflammatory reaction $(H$ and $E ; \times 125)$. (B) Higher magnification showing vacuolization of acinar cells without necrosis $(H$ and $E ; \times 325)$.

libitum. Plasma CCK concentrations in mice receiving subcutaneous injections of proglumide $(400 \mathrm{mg} / \mathrm{kg})$ every $6 \mathrm{~h}$ for 60 $\mathrm{h}$, whether receiving the chow or CDE diets ad libitum, were not significantly different from those measured in saline-injected controls on the same diets $(5.5 \pm 0.6[n=4]$ for chow-fed mice and 1.8 $\pm 0.4[n=5]$ for CDE-diet-fed mice; $P>0.1)$.

Because CCK levels were low in animals on the CDE diet, it was important to determine if there was an inhibitor of CCK bioactivity in plasma that could interfere with the bioassay. To investigate this possibility, two experiments were performed. First, exogenous CCK-8 was added to plasma collected from normal mice and mice fed the CDE diet for $54 \mathrm{~h}$. Plasma was then extracted and assayed for CCK bioactivity. The 54-h recoveries of exogenous CCK were $93 \pm 10 \%$ (mean \pm SD, $n=7$ ) from normal mice and $73 \pm 2 \%(n=4)$ from CDE-fed mice. Since this small difference in recoveries of CCK would not account for the marked suppression of CCK levels found in CDEtreated mice, a second study was done to determine if the recovery of CCK injected into CDE-fed mice was lower than that of normal animals. Normal mice and mice on the CDE diet for $30 \mathrm{~h}(n=25$ in each group) were injected subcutaneously with 


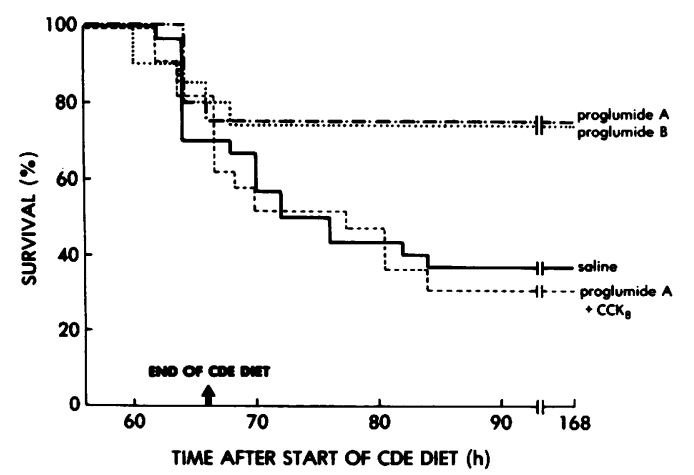

Figure 6. Cumulative survival. Proglumide A represents experiments in which proglumide was given from the start of the CDE diet (prophylactic regimen), whereas proglumide $B$ represents experiments in which proglumide was given only after the rats had been fed the CDE diet for $33 \mathrm{~h}$ (therapeutic regimen). Both the prophylactic and therapeutic proglumide treatments significantly improved survival compared to the saline-injected control $(P<0.01$ by chi-square test). Injections of CCK-8 in addition to the prophylactic proglumide treatment (proglumide A + CCK-8), however, completely abolished the beneficial effect on survival $(P>0.30$ compared with the saline-injected control group). For survival data see also Table II.

$2 \mu \mathrm{g} / \mathrm{kg} \mathrm{CCK}-8$. Animals were sacrificed $30 \mathrm{~min}$ after injection and blood was collected for CCK assay. Plasma CCK levels in normal mice injected with CCK averaged 17.3 $\pm 4.4 \mathrm{pM}$ (mean $\pm \mathrm{SD}, n=9$ ) whereas those of CDE-treated mice were $32 \pm 5.3 \mathrm{pM}(n=6)$.

\section{Discussion}

The protease inhibitor gabexate had dramatic beneficial effects on survival and biochemical and histological alterations in this model of acute hemorrhagic pancreatitis when given before the onset of pancreatitis. The beneficial effects were essentially lost when gabexate was given later after initiation of acute pancreatitis, although the protease inhibitor still significantly decreased

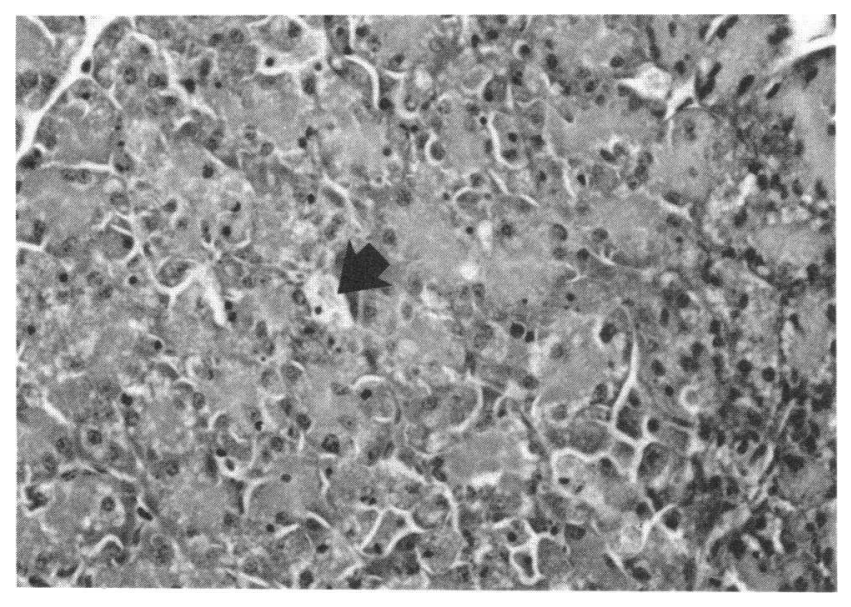

Figure 7. Pancreatic histology from mice after $54 \mathrm{~h}$ on CDE diet, which received s.c. injections of $400 \mathrm{mg} / \mathrm{kg}$ proglumide and $2 \mu \mathrm{g} / \mathrm{kg}$ CCK-8 every $6 \mathrm{~h}$ while on the CDE diet, showing multiple cytoplasmic vacuoles in acinar cells and focal cell necrosis (arrow) $(H$ and $E, \times 225)$.

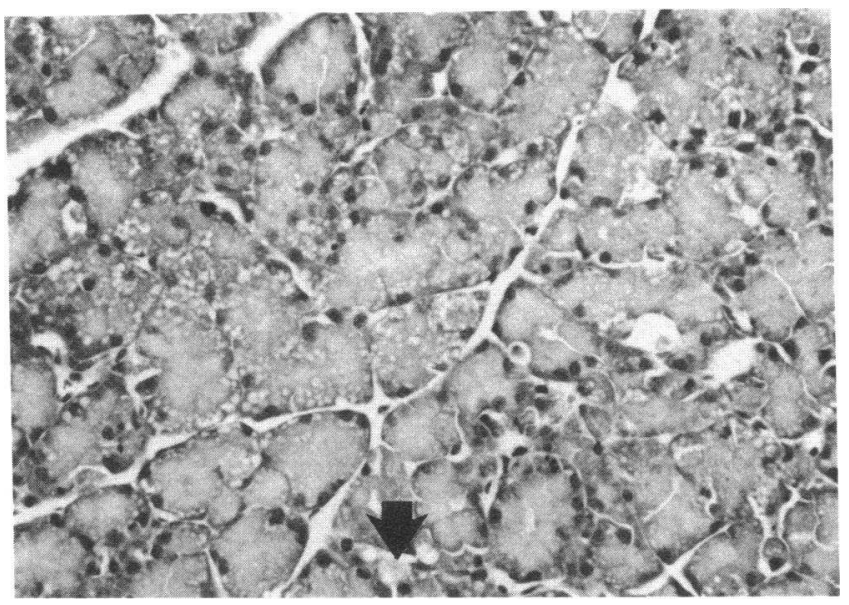

Figure 8. Pancreatic histology from mice after $54 \mathrm{~h}$ on the CDE diet, which received s.c. injections of $25 \mathrm{U} / \mathrm{kg}$ secretin avery $6 \mathrm{~h}$ while on the CDE diet, showing vacuolization of acinar cells and occasional cell necrosis (arrow) $(H$ and $E ; \times 325)$.

the amount of activated pancreatic trypsin. These observations cast some doubt on the potential for use of this protease inhibitor in human disease, where one is usually confronted with acute pancreatitis already far enough advanced to cause significant symptoms. The earlier protease inhibitor aprotinin (Trasylol) had been shown to be ineffective in the CDE diet model used in the present study, even as a prophylactic treatment (11) and in human acute pancreatitis $(12,13)$. The dramatic beneficial effect seen with the prophylactic gabexate treatment in the present study contrasts with the ineffectiveness seen with aprotinin. This likely reflects the theoretical advantages that recently developed serine protease inhibitors have, compared with aprotinin. Gabexate is more potent and inhibits a greater number of proteolytic enzymes than does aprotinin $(14,15)$. With the development of even more potent protease inhibitors, such as camostate (FOY 305), which has a chemical structure similar to gabexate $(14,16,17)$, a beneficial (or therapeutic) effect may be achieved even when the protease inhibitor is given later during the time course of acute pancreatitis. Thus, the present results suggest the need for further studies of the inhibition of tryptic activity and that of other serine proteases as a therapeutic factor in acute pancreatitis.

Secretin had been proposed to be protective against caeruleininduced acute pancreatitis in rats and dogs $(2,3)$. Subsequent studies in the caerulein model in mice $(1,18)$ and in a model employing injections of bile salts into the pancreatic duct of rats $(19,20)$ did not show any major beneficial effect of secretin. The present results show that secretin had only very limited beneficial effects on the histological alterations and did not significantly ameliorate mortality or the biochemical alterations. The dose of secretin used in the present study was chosen from previous data, which showed that this dose of secretin had a small beneficial effect on caerulein-induced acute pancreatitis in mice (1). Thus, both the present results and our previous study (1) indicate that secretin may have some small beneficial effect when given as a prophylactic treatment, but its therapeutic role in acute pancreatitis appears to be rather limited.

We have previously shown that the CCK-receptor antagonist proglumide had marked protective effects against caerulein-in- 

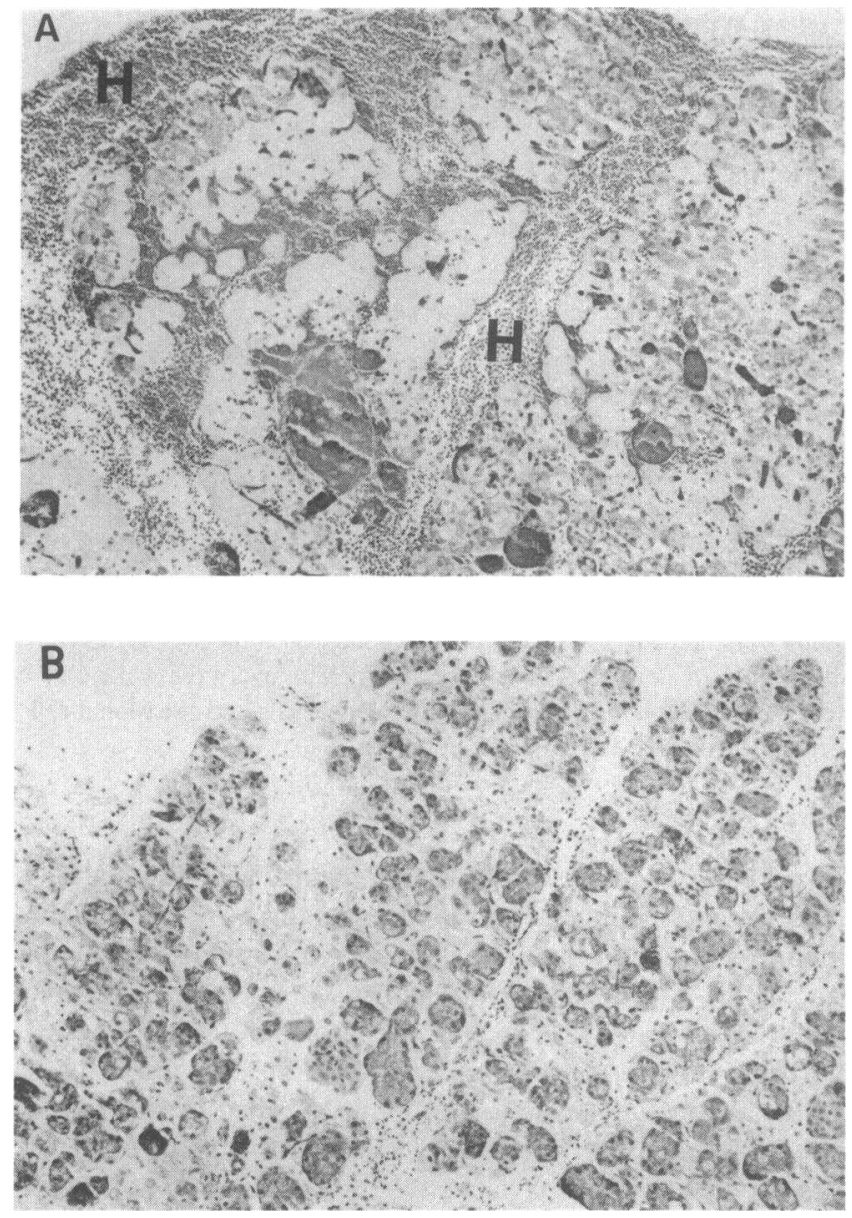

Figure 9. Pancreatic histology from mice after $54 \mathrm{~h}$ on the CDE diet, which received s.c. injections of $2 \mu \mathrm{g} / \mathrm{kg}$ CCK-8 every $6 \mathrm{~h}$ while on the $\mathrm{CDE}$ diet. $(A)$ Massive necrosis of acinar tissue. Perilobular hemorrhage is also present $(H)(H$ and $E ; \times 125)$. (B) Another section showing large areas of necrosis ( $>50 \%$ of gland) and an associated inflammatory reaction ( $H$ and $E ; \times 125$ ).

duced acute pancreatitis in mice (1). The finding that blockade of CCK receptors protects against injury mediated by caerulein, a peptide with CCK activity, appears rather evident; but it led us to the more general hypothesis that blockade of CCK receptors, and thereby inhibition of stimulation of enzyme secretion, may also be beneficial in other models of acute pancreatitis and, potentially, in human disease (1). The present study, therefore, evaluated the effects of a CCK-receptor antagonist in a model of acute pancreatitis (CDE diet) in which the injury is thought not to be directly caused or mediated by CCK receptors or CCK hyperstimulation. The results were striking. Proglumide not only had marked protective (or prophylactic) effects on survival, histology, serum enzymes, and pancreatic activated trypsin when given early in the course of acute pancreatitis, but in contrast to the protease inhibitor gabexate, also had marked beneficial (therapeutic) effects when given after significant pancreatitis had already been initiated. Proglumide exerted its beneficial effects even though plasma CCK levels were normal (or even decreased) throughout the time period of feeding the CDE diet in this model of acute pancreatitis. Thus, CCK, even at physiologic concentrations, appears to play an important permissive or contributory role in the development of acute pancreatitis in this model.
Plasma CCK concentrations were significantly decreased in the CDE-fed mice as compared with chow-fed controls. This was unexpected because a previous study had reported that secretion of digestive enzymes is decreased from pancreatic acini isolated from mice fed a CDE diet (21). Thus, decreased intraluminal trypsin in the small intestine might be expected to lead to an increase in plasma CCK by loss of a feedback inhibitory mechanism as has been described in the rat (22). The reasons for the unexpectedly low CCK concentrations in CDE-fed mice are unknown; it might be attributable to decreased food intake, a delay in gastric emptying, or altered amino acid composition of the food (CDE diet vs. chow). Also, the metabolism of circulating CCK might be considerably altered due to the severe disease state caused by the CDE diet.

Further control experiments were done to clarify if proglumide exerted its beneficial effects by a blockade of CCK receptors rather than some unknown, nonspecific mechanism unrelated to CCK. In these studies we sought to overcome the beneficial effect of proglumide by additional injections of exogenous CCK-8. To remove proglumide from the CCK receptors, a dose of CCK-8 had been chosen that would result in plasma CCK concentrations that were somewhat higher than physiologic CCK concentrations. The dose chosen (subcutaneous [s.c.] injections of $2 \mu \mathrm{g} / \mathrm{kg} \mathrm{CCK}-8$ at 6-h intervals) did not, by itself, cause any biochemical or histological evidence of acute pancreatitis. The CCK injections shortly before proglumide administration completely abolished the beneficial effects seen with the prophylactic treatment by the CCK-receptor antagonist. This strongly suggests that proglumide's protection is mediated by CCK receptors and not by some other nonspecific mechanism.

In addition, CCK injections also reduced the beneficial effect seen with the prophylactic gabexate treatment. Furthermore, CCK-8 worsened the severity of acute pancreatitis caused by the CDE diet alone (at least in terms of the biochemical and histological alterations, whereas the reduction in survival did not reach statistical significance). These observations further support the suggestion that CCK may play an important permissive or contributory role in the development of acute pancreatitis. In a previous study, caerulein had been shown to worsen the severity and mortality in a rat model of acute pancreatitis employing intraductal injections of bile salts (20). The mechanisms by which CCK contributes to the development of acute pancreatitis and by which blockade of CCK receptors ameliorates acute pancreatitis are unknown. However, it appears unlikely that the beneficial effect of CCK-receptor blockade is merely due to a decrease in the amount of enzyme that is secreted into the acinar and ductal lumen, because other substances that can decrease enzyme secretion (such as atropine and glucagon) have failed to show beneficial effects in acute pancreatitis $(15,23,24)$. It appears more likely that inhibition of intracellular events related to stimulus-secretion coupling are responsible for the effect of CCK-receptor antagonists.

The dose of proglumide shown to have beneficial effects in this and a previous study is rather high $(400 \mathrm{mg} / \mathrm{kg}$ every $6 \mathrm{~h}$ in the present study or $400 \mathrm{mg} / \mathrm{kg}$ per $\mathrm{h}$ in the previous study [1]). This would require doses of $28 \mathrm{~g}$ proglumide per injection for a 70-kg patient, which cannot be administered in clinical practice. However, proglumide analogues and a nonpeptide CCK receptor antagonist isolated from Aspergillus alliaceus have recently been developed that are 75-1,000 times more potent than proglumide (25-27). Thus, the dose of a more potent proglumide analogue 
required for effective CCK receptor blockade in a human, potentially having a beneficial effect on acute pancreatitis, may be comparable to doses of cimetidine or ranitidine required to inhibit gastric acid secretion and accelerate duodenal ulcer healing.

\section{Acknowledgments}

The authors thank Diana Fedorchak and Michael Karasik for their editorial assistance.

This work was supported by U. S. Public Health Services grant AM01291 and grants from the Research Evaluation and Allocation Committee and the Committee on Research of the Academic Senate, School of Medicine, University of California, San Francisco, CA. Dr. Niederau was supported by a grant of the Deutsche Forschungsgemeinschaft (DFG Ni 224/1-1).

\section{References}

1. Niederau, C., L. D. Ferrell, and J. H. Grendell. 1985. Caeruleininduced acute necrotizing pancreatitis in mice: protective effects of proglumide, benzotript, and secretin. Gastroenterology. 88:1192-1204.

2. Renner, I. G., and J. R. Wisner, Jr. 1983. Protective effects of exogenous secretin on ceruletide-induced acute pancreatitis in rat. $J$. Clin. Invest. 72:1081-1092.

3. Renner, I. G., and J. R. Wisner, Jr. 1986. Ceruletide-induced acute pancreatitis in the dog and its amelioration by exogenous secretion. Int. J. Pancreatol. 1:39-49.

4. Lankisch, P. G., B. Göke, F. Stöckmann, J. Otto, and W. Creutzfeldt. 1983. Effect of gabexate mesilate on pancreatic secretion and on acute pancreatitis in rats. Dig. Dis. Sci. 28:937. (Abstr.)

5. Lombardi, B., L. W. Estes, and D. S. Longnecker. 1975. Acute hemorrhagic pancreatitis (massive necrosis) with fat necrosis induced in mice by dl-ethionine fed with a choline deficient diet. Am. J. Pathol. 79: 465-76.

6. Coelle, E. F., I. L. Taylor, K. Lewin, and N. Adham. 1983. Beneficial effect of pancreatic polypeptide in experimental pancreatitis. Dig. Dis. Sci. 28:1083-1087.

7. Rinderknecht, H., I. G. Renner, and C. Carmack. 1976. Activation of human pancreatic juice. Clin. Chim. Acta. 73:369-372.

8. Lowry, O. H., N. J. Rosebrough, A. L. Farr, and R. J. Randall. 1951. Protein measurements with the Folin phenol reagent. J. Biol. Chem. 193:265-275.

9. Liddle, R. A., I. D. Goldfine, and J. A. Williams. 1984. Bioassay of plasma cholecystokinin in rats: effects of food, trypsin inhibitor, and alcohol. Gastroenterology. 87:542-549.

10. Liddle, R. A., I. D. Goldfine, M. S. Rosen, R. A. Taplitz, and J. A. Williams. 1985. Cholecystokinin bioactivity in human plasma: molecular forms, responses to feeding, and relationship to gallbladder contraction. J. Clin. Invest. 75:1144-1152.

11. Manabe, T., and M. L. Steer. 1979. Protease inhibitors and experimental acute hemorrhagic pancreatitis. Ann. Surg. 190:13-17.
12. Imrie, C. W., I. S. Benjamin, J. C. Ferguson, et al. 1978. A singlecentre double-blind trial of trasylol therapy in primary acute pancreatitis. Br. J. Surg. 65:337-341.

13. M.R.C. Working Party. 1977. Death from acute pancreatitis. M.R.C. multicentre trial of glucagon and aprotinin. Lancet. ii:632-635.

14. Tamura, Y., M. Hirado, K. Okamura, Y. Minato, and S. Fujii. 1977. Synthetic inhibitors of trypsin, plasmin, kallikrein, thrombin, $C_{1} r$, and $C_{1}$ esterase. Biochim. Biophys. Acta. 484:417-422.

15. Takasugi, S., and N. Toki. 1980. Inhibitory effects of native and synthetic protease inhibitors on plasma proteases in acute pancreatitis. Hiroshima J. Med. Sci. 29:189-194.

16. Takasugi, S., H. Yonezawa, N. Ikei, and T. Kanno. 1982. Prevention of acute experimental pancreatitis in rats and dogs by intraduodenal infusion of a synthetic trypsin inhibitor. Digestion. 24:36-41.

17. Göke, B., F. Stöckmann, R. Müller, P. G. Lankisch, and W. Creutzfeldt. 1984. Effect of a specific serine protease inhibitor on the rat pancreas: systemic administration of camostate and exocrine pancreatic secretion. Digestion. 30:171-178.

18. Adler, G., V. Keim, F. J. Haberich, H. F. Kern, and R. Arnold. 1983. Secretin treatment in hormone-induced pancreatitis in the rat. Dig. Dis. Sci. 28:923. (Abstr.)

19. Lankisch, P. G., B. Göke, U. R. Fölsch, K. Winckler, J. Otto, and W. Creutzfeldt. 1983. Influence of secretin on the course of acute experimental pancreatitis in rats. Digestion. 26:187-191.

20. Evander, A., I. Lundquist, and I. Ihse. 1982. Influence of gastrointestinal hormones on the course of acute experimental pancreatitis. Hepato-gastroenterology. 29:161-166.

21. Gilliland, L., and M. L. Steer. 1980. Effects of ethionine on digestive enzyme synthesis and discharge by mouse pancreas. Am. J. Physiol. 239:G418-G426.

22. Miyasaka, K., and G. M. Green. 1984. Effect of partial exclusion of pancreatic juice on rat basal pancreatic secretion. Gastroenterology. 86:114-119.

23. Cameron, J. L., D. Mehigan, and G. D. Zuidema. 1979. Evaluation of atropine in acute pancreatitis. Surg. Gynecol. Obstet. 148:206208.

24. Dürr, H. K., D. Maroske, O. Zelder, and J. C. H. Bode. 1978. Glucagon therapy in acute pancreatitis. Gut. 19:175-179.

25. Jensen, R. T., R. B. Murphy, M. Trampotta, L. H. Schneider, S. W. Jones, J. M. Howard, and J. D. Gardener. 1985. Proglumide analogues: potent cholecystokinin receptor antagonists. Am. J. Physiol. 249: G214-G220.

26. Niederau, C., M. Niederau, J. A. Williams, and J. H. Grendell. 1986. New proglumide-analogue cholecystokinin receptor antagonists: very potent and selective for peripheral tissues. Am. J. Physiol. 251: G856-G860.

27. Chang, R. S. L., V. J. Lotti, R. L. Monaghan, J. Birnbaum, E. O. Stapley, M. A. Goetz, G. Albers-Schönberg, A. A. Patchett, J. M. Liesch, O. D. Hensens, and J. P. Springer. 1985. A potent nonpeptide cholecystokinin receptor antagonist selective for peripheral tissue isolated from Aspergillus alliaceus. Science (Wash. DC). 230:177-179. 